\title{
12. BIOSTRATIGRAPHY OF EOCENE TO OLIGOCENE DEEP-WATER AGGLUTINATED FORAMINIFERS IN THE RED CLAYS FROM SITE 767, CELEBES SEA ${ }^{1}$
}

\author{
Michael A. Kaminski ${ }^{2,3}$ and Zehui Huang ${ }^{4}$
}

\begin{abstract}
Deep-water agglutinated foraminifers were examined from reddish brown claystones comprising lithologic Unit 4 of Ocean Drilling Program Holes 767B and 767C. The biostratigraphy of deep-water agglutinated foraminifers in this unit indicates an Eocene to Oligocene age. The assemblages are cosmopolitan, not endemic, and several species that are useful biostratigraphic indicators in the Atlantic and western Mediterranean region (e.g., Reticulophragmium amplectens, Reophax elongatus, Ammodiscus latus, Rzehakina epigona minima, Hormosina ovulum ovulum, and Paratrochamminoides spp.) are present in the Celebes Sea. Based on biostratigraphic correlations with the North Atlantic and Alpine-Carpathian regions, the base of the sedimentary section in Hole 767C is determined to be of early Eocene, not middle Eocene age as determined by shipboard biostratigraphic analyses. The Eocene/ Oligocene boundary is represented by a hiatus or extremely condensed interval.
\end{abstract}

\section{INTRODUCTION}

The Celebes Sea in the western Pacific is a small oceanic basin within the Eurasian Plate in an area of active collisional tectonics. It is an excellent modern analog of the small oceanic basins that are preserved as obducted fragments in the alpine areas of southern and central Europe. The Celebes Sea, together with the Sulu and Banda basins, are thought to represent a trapped fragment of an originally continuous, once-larger ocean basin, while other basins in the area are thought to have originated by back-arc spreading. The primary goal of Leg 124 was to determine the age, stratigraphy, and paleoceanography of the Celebes Sea and the Sulu Basin to the north, to reconstruct the history of tectonic and paleoceanographic events in the area.

Site 767 is located at $4916 \mathrm{~m}$ depth in the central portion of the Celebes Sea (Fig. 1). Drilling at the site recovered a complete sedimentary section overlying plagioclase-olivine basalt. The lowermost lithologic unit at Site 767 (lithologic Unit 4) consists of deep-sea reddish claystones that are barren of calcareous planktonic microfossils, but contain a nearly continuous record of deep-water agglutinated foraminifers (DWAF). In this study, we examined samples from lithologic Unit 4 to determine the nature of DWAF assemblages and thereby constrain the chronostratigraphy and paleoecology of the oldest sediments in the Celebes Sea.

\section{PREVIOUS STUDIES}

Very little is known about Eocene-Oligocene DWAF assemblages from the western Pacific margin. DWAF assemblages of undoubtedly Paleocene age from DSDP Site 283 were studied by Webb (1975), which was drilled between Tasmania and New Zealand. Webb's study is significant

\footnotetext{
${ }^{1}$ Silver, E. A., Rangin, C., von Breymann, M. T., et al., 1991. Proc. ODP, Sci. Results, 124: College Station, TX (Ocean Drilling Program).

2 Department of Paleoceanography, GEOMAR, Wischhofstr. 1-3, D-2300 Kiel 14, Federal Republic of Germany.

${ }^{3}$ Present affiliations: Department of Geological Sciences, University College London, Gower Street, London WC1E 6BT, U.K., and Department of Paleoceanography, GEOMAR, Wischhofstr. 1-3, D-2300 Kiel 14, Federal Republic of Germany.

${ }^{4}$ Centre for Marine Geology, Dalhousie University, Halifax, N.S. B3H 3J5, Canada.
}

because it was the first to document the occurrence in the Pacific Basin of DWAF taxa first described from the western Tethys, thereby documenting the cosmopolitan nature of these forms. Additional occurrences of some Paleocene and lowermost Eocene DWAF taxa in southern New Guinea were noted by Haig (1982). Our study is the first report of DWAF taxa in younger sediments from the western Pacific basins.

Fortunately, a large body of information on the biostratigraphy of Paleogene DWAF is available from the western Mediterranean and in the marginal basins of the Atlantic. Although these records are rather distant from the Celebes Sea, they can nevertheless serve as useful comparative material given the absence of any reference sections in the western Pacific. A formal zonation based on first and last occurrences has been developed for the Paleocene to Eocene for the Polish Carpathians by Geroch and Nowak (1984) and Geroch and Koszarski (1988). The succession of DWAF assemblages in the Skole Basin of the Carpathians, based on semiquantitative faunal abundance data, was discussed by Morgiel and Szymakowska (1978). In addition to these localities, there are several studies from the Atlantic margins that can serve as reference sections. The Campanian to lower Eocene biostratigraphy of DWAF in southern Trinidad was studied by Kaminski et al. (1988); the Eocene to Oligocene biostratigraphy of DWAF in Hole $647 \mathrm{~A}$ in the southern Labrador Sea was reported by Kaminski et al. (1989), and the Eocene to lower Miocene biostratigraphy of DWAF in Hole 643A in the Norwegian Sea was reported by Kaminski et al. (1990). The Cenozoic record of DWAF in the North Sea was investigated by Gradstein et al. (1988), Charnock and Jones (1990) and by Gradstein et al. (in press).

\section{METHODS}

A total of 28 samples from lithologic Unit 4 in Holes 767B and 767C (Cores 124-767B-72X through 124-767C-12R) were studied for foraminifers. Samples, averaging $20 \mathrm{~cm}^{3}$ in volume, were dried overnight in a $60^{\circ}$ oven, boiled in a $1 \%$ Calgon solution, and washed over a $63-\mu \mathrm{m}$ sieve. All foraminifers were picked from the whole fraction $>63 \mu \mathrm{m}$ according to standard micropaleontologic techniques. Specimens were mounted on cardboard reference slides, and specimens were illustrated by scanning electron microscopy (SEM). See Plates 

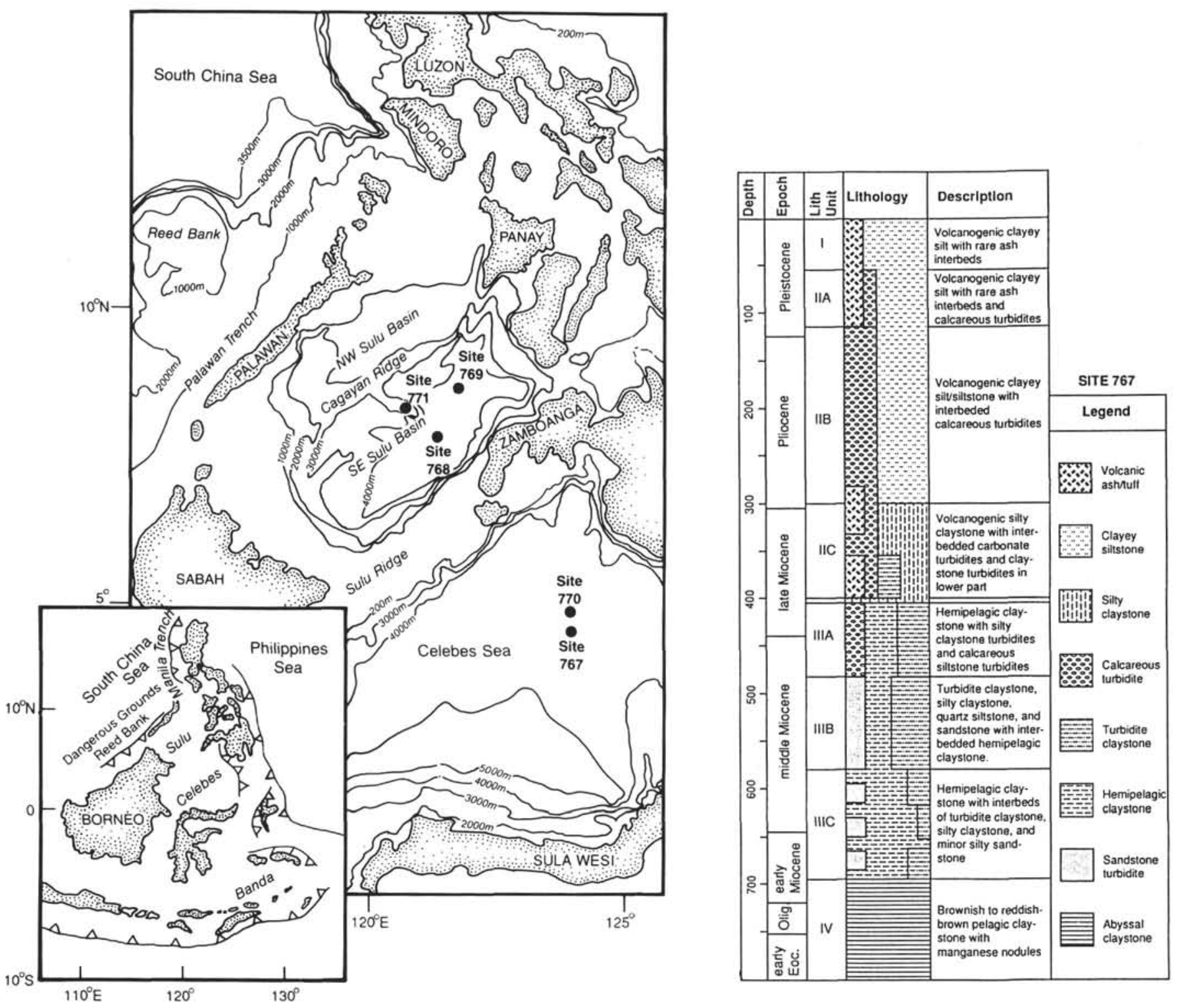

Figure 1. Location of ODP Site 767 in the Celebes Sea, with lithology and chronostratigraphy determined during Leg 124 (modified from Leg 124 Shipboard Scientific Party, 1989a, 1989b).

1-3. Plesiotypes are housed in M.A.K.'s collection at University College London.

\section{LITHOLOGY}

Lithologic Unit 4 is composed mainly of dark grayish brown to reddish brown claystone. The claystone is generally homogeneous and structureless in the upper part, becoming more bioturbated downward and finally more laminated near the base of the unit. Laminations are color variations possibly caused by variations in the concentrations of manganese oxides. Sand-size particles consist mainly of biogenic components (agglutinated foraminifers, radiolarians, and fish remains) and small manganese nodules. Zeolites occur as discrete crystals in the lower half of the unit. The carbonate content is very low throughout the section $(0.2 \%)$. The fine grain size and color of the claystone unit, along with the presence of manganese nodules and fish remains, indicate slow pelagic sedimentation below the calcite compensation depth (CCD).

\section{RESULTS}

Biostratigraphy

The red clays from Site 767 are barren of calcareous microfossils, and shipboard biostratigraphy was based solely on radiolarians and ichthyoliths (Site 767, Rangin, Silver, von Breymann, et al., 1990). The benthic foraminifer assemblages and the interpreted chronostratigraphy determined in Site 767 are illustrated in Figure 2; the characteristic assemblages are described below in order from oldest to youngest. For comparison, the shipboard radiolarian and ichthyolith data are also shown. Radiolarian assemblages throughout the interval were found only in isolated samples, but offered the best stratigraphic resolution, especially in the Oligocene. Radiolarian assemblages at the base of Hole $767 \mathrm{C}$ were poorly preserved, and only tentatively assigned to the $P$. chalara- $P$. goetheana Zones (Rangin, Silver, von Breymann, et al., 1990). 


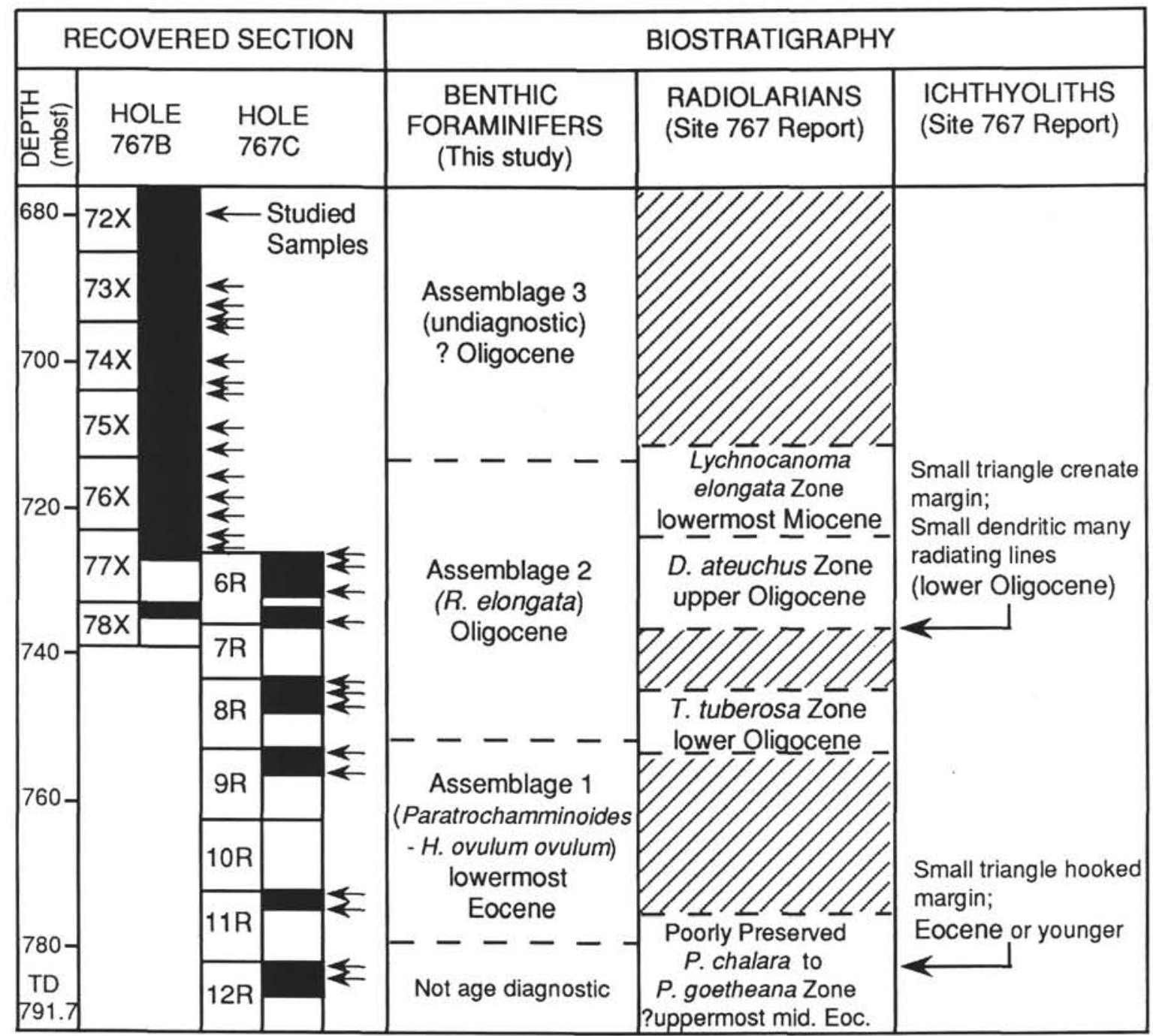

Figure 2. Core recovery, studied samples, and chronostratigraphy of microfossil assemblages from the red clays (lithologic Unit 4) at ODP Site 767. Radiolarian and ichthyolith data were compiled from the Site 767 Chapter (Rangin, Silver, von Breymann et al. 1990). Barren intervals are indicated by diagonal lines.

1. Assemblage 1 (Paratrochamminoides-Hormosina ovulum ovulum)

Interval: Core 124-767C-11R-Core 124-767C-9R

Age: early Eocene

Sediments directly overlying basement in Core 124-767C$12 \mathrm{R}$ are nearly barren of benthic foraminifers, and our two samples from this core contain only fragments of Rhizammina. Above this interval, however, the samples from Cores 124-767C-11R and 124-767C-9R contain abundant DWAF assemblages comprised of about 36 taxa (Table 1). The assemblages are dominated by fragments of tubular genera, such as Rhizammina, Rhabdammina, and Bathysiphon. However, some very distinctive species that are useful biostratigraphic indicators also occur in this assemblage, including Spiroplectammina spectabilis (Grzybowski), Reophax nodulosus Brady, Kalamopsis grzybowskii (Dylazanka), Hormosina ovulum ovulum (Grzybowski), Hormosina ovuloides (Grzybowski), Rzehakina epigona minima Cushman and Renz, Hyperammina rugosa Verdenius and Van Hinte, Praecystammina sp., and Paratrochamminoides spp. The occurrence of most of these species is rare and sporadic, but allows us to determine the age of the interval as early Eocene (see below). The top of this assemblage is determined by the last occurrence of these species in Core 124-767C-9R.

2. Assemblage 2 (Reophax elongatus)

Interval: Core 124-767C-8R-Section 124-767B-75X-4

Age: latest early Eocene to early Oligocene

This assemblage corresponds to the total range of Reophax elongatus (Grzybowski) in the studied section (Tables 1, 2). The first occurrence (FO) of $R$. elongatus is coincident with the FO of Reticulophragmium amplectens in Sample 124767C-8R-2, 30-34 cm. The last occurrence (LO) of Reophax elongatus in Sample 124-767B-75X-4, 45-48 cm also coincides with the LO's of Haplophragmoides walteri walteri (Grzybowski) and Ammodiscus latus (Grzybowski). The abundance of DWAF in samples from this interval is markedly lower than in the underlying assemblage, but the diversity across the whole interval is only slightly lower (31 vs. 36 taxa). This assemblage contains several taxa that are typical of middle to upper Eocene sediments in the Atlantic and western Tethys, such as $R$. amplectens, $R$. elongatus, Haplophragmoides walteri walteri, Haplophragmoides horridus (Grzybowski) and Karrerulina conversa (Grzybowski). 
Table 1. Benthic foraminifers abundance data from ODP Hole 767B. $R=1-3$ specimens; $F=$ frequent. $4-9$ specimens; $C=$ common, $10-29$ specimens; $\mathbf{A}=$ abundant, $\mathbf{3 0}$ or more specimens.

\begin{tabular}{|c|c|c|c|c|c|c|c|c|c|c|c|c|c|c|c|}
\hline $\begin{array}{r}\text { Core-Section: } \\
\text { Interval in cm: } \\
\text { AGE: } \\
\text { No. of species: }\end{array}$ & $\begin{array}{c}72 \times-3 \\
23-25 \\
\text { ?Olig. } \\
8\end{array}$ & $\begin{array}{c}73 \times-4 \\
92-95 \\
\text { ?Olig. } \\
0 \\
\text { Barren }\end{array}$ & $\begin{array}{c}73 \times-5 \\
126-130 \\
\text { ?Olig. } \\
0 \\
\text { Barren }\end{array}$ & $\begin{array}{c}73 \times-6 \\
51-57 \\
\text { ?Olig. } \\
0 \\
\text { Barren }\end{array}$ & $\begin{array}{c}74 X-1 \\
108-113 \\
\text { ?Olig. } \\
0 \\
\text { Barren }\end{array}$ & $\begin{array}{c}74 \times-4 \\
69-74 \\
? \text { Olig. } \\
5\end{array}$ & $\begin{array}{c}74 X-6 \\
79-82 \\
\text { ?Olig. } \\
0 \\
\text { Barren }\end{array}$ & $\begin{array}{c}75 X-1 \\
45-48 \\
\text { Olig. } \\
6\end{array}$ & $\begin{array}{c}75 \times-4 \\
45.48 \\
\text { Olig. } \\
10\end{array}$ & $\begin{array}{c}75 \times-6 \\
80-83 \\
\text { Olig. } \\
9\end{array}$ & $\begin{array}{c}76 \times-2 \\
111-113 \\
\text { Olig. } \\
7\end{array}$ & $\begin{array}{c}76 \times-4 \\
94-96 \\
\text { Olig. } \\
0 \\
\text { Barren }\end{array}$ & $\begin{array}{c}76 \times-6 \\
6-9 \\
\text { Olig. } \\
6\end{array}$ & $\begin{array}{c}77 \times-1 \\
88-90 \\
\text { Olig. } \\
5\end{array}$ & $\begin{array}{c}77 \times-2 \\
30-34 \\
\text { Olig. } \\
7\end{array}$ \\
\hline Rhizammina indivisa & $\mathrm{C}$ & & & & & $\mathrm{R}$ & & & & $F$ & & & $\mathrm{C}$ & & \\
\hline Ammosphaeroidina pseudopauciloculata & $\mathrm{F}$ & & & & & & & & & & & & & & \\
\hline Hyperammina spp. & R & & & & & & & & & & R & & & & \\
\hline Lituotuba lituiformis & $\mathrm{R}$ & & & & & & & & & & & & & & \\
\hline Trochammina sp. & $\mathrm{R}$ & & & & & & & & & & & & & & \\
\hline Reticulophragmium amplectens & $\mathrm{F}$ & & & & & & & A & & $\mathrm{R}$ & & & & & $\mathrm{F}$ \\
\hline Reophax nodulosus & $\mathrm{R}$ & & & & & R & & & & & & & & & \\
\hline Hormosinella sp. & $\mathrm{R}$ & & & & & & & & & & & & & & \\
\hline G/omospira charoides & & & & & & R & & $\mathrm{F}$ & $\mathrm{F}$ & $\mathrm{F}$ & & & & & \\
\hline Glomospira gordialis & & & & & & $\mathrm{F}$ & & $\mathrm{F}$ & $\mathrm{F}$ & $\mathrm{F}$ & $\mathrm{R}$ & & & & \\
\hline Glomospira glomerata & & & & & & $\mathrm{R}$ & & $\mathrm{R}$ & & & & & & & \\
\hline Ammodiscus tenuissimus & & & & & & & & R & A & $\mathrm{R}$ & R & & & & \\
\hline Rhabdammina spp. & & & & & & & & $\mathrm{F}$ & C & & $\mathrm{C}$ & & $\mathrm{F}$ & $\mathbf{F}$ & C \\
\hline Ammodiscus latus & & & & & & & & & $\mathrm{F}$ & $\mathrm{R}$ & & & $\mathrm{R}$ & & \\
\hline Reophax elongatus & & & & & & & & & R & & & & & & R \\
\hline Bathysiphon spp. & & & & & & & & & $\mathrm{F}$ & $\mathrm{F}$ & $\mathrm{F}$ & & & $F$ & $\mathrm{~F}$ \\
\hline Haplophragmoides walteri walteri & & & & & & & & & $\mathrm{R}$ & & $\mathrm{R}$ & & & & \\
\hline Glomospira irregularis & & & & & & & & & $\mathrm{R}$ & $\mathrm{F}$ & & & & & \\
\hline Ammodiscus peruvianus & & & & & & & & & R & $R$ & & & & & \\
\hline Hormosina velascoensis & & & & & & & & & & & A & & R & & \\
\hline Trochamminoides variolarius & & & & & & & & & & & & & R & & \\
\hline Saccammina grzybowskii & & & & & & & & & & & & & R & & \\
\hline Haplophragmoides walteri excavatus & & & & & & & & & & & & & & R & \\
\hline Psammosphaera sp. & & & & & & & & & & & & & & $\mathrm{A}$ & \\
\hline Haplophragmoides eggeri & & & & & & & & & & & & & & $\mathrm{R}$ & \\
\hline Hyperammina sp. (large, coarse) & & & & & & & & & & & & & & & R \\
\hline Cyclammina placenta & & & & & & & & & & & & & & & $\mathrm{R}$ \\
\hline
\end{tabular}

\section{Assemblage 3 (undiagnostic)}

Interval: Sample 124-767B-75X-1, 45-48 cm-Sample 124-767B$72 \mathrm{X}-3,23-25 \mathrm{~cm}$

Age: ? Oligocene

This assemblage at the top of the studied section displays much lower diversity than the underlying assemblages (only 12 taxa), and five of the eight samples studied were barren. The foraminifer assemblage is characterized by scattered occurrences of mostly long-ranging forms, such as Rhizammina, Lituotuba, Reophax nodulosus, and species of Glomospira. However, the occurrences of Reticulophragmium amplectens in the uppermost sample suggest an age no younger than Oligocene for this interval.

\section{DISCUSSION}

\section{The Age of Basement in the Celebes Sea}

In a geophysical survey of the Celebes Sea, Weissel (1980) determined an Eocene age for the oceanic crust preserved in the area using three lines of evidence. (1) using an average crustal depth of 6-7 km and a sediment thickness of $2 \mathrm{~km}$, Weissel estimated an age of 50-55 Ma based on a comparison with the empirical oceanic age vs. depth relationship of Sclater et al. (1971); (2) a compilation of the available heatflow data collected in the Celebes Sea yielded (after ignoring two anomalously low values) an average observed mean heat flow of $1.58 \mathrm{HFU}\left(\mu \mathrm{cal} \mathrm{cm} \mathrm{cm}^{-2} \cdot \mathrm{s}^{-2}\right)$. A comparison with the cooling half-space model of Parsons and Sclater (1977) yielded an estimated age of about 51 Ma (3) a marine magnetic anomaly survey in the southwestern part of the basin yielded an anomaly pattern that was tentatively interpreted as Anomalies 18, 19, and 20 (42-47 Ma). This age of $42 \mathrm{Ma}$ was accepted for the formation of the Celebes Sea by the Leg 124 Shipboard Scientific Party (1989a).

\section{Evidence for an Early Eocene Age for the Base of Hole 767C}

All lines of benthic faunal evidence converge in indicating an Early Eocene age for the base of the sedimentary section at Site 767. This age assignment is based on correlations with the biostratigraphic record in the Carpathians, Trinidad, Labrador, and the North Sea, using the following criteria:

1. Reophax nodulosus-This species has its FO near the Paleocene/Eocene boundary, according to Geroch and Nowak (1984). In the Atlantic, it is predominantly an abyssal taxon and occurs commonly in the Eocene at Sites 647 and 643. The occurrence of this species and the absence of any Paleocene taxa in Hole $767 \mathrm{C}$ rules out a Paleocene age.

2. Rzehakina epigona minima-Cushman and Renz (1946) first described Rzehakina epigona minima from the "upper zone" of the Lizard Springs Formation (i.e., the lower Eocene portion), but we have not been able to verify this occurrence. We have observed $R$. epigona minima in the upper Campanian to upper Paleocene (Zone P4) in the Guayaguayare and lower Lizard Springs Formations in Trinidad (Kaminski et al., 1988). In the central North Sea, it is always found below the lowermost Eocene tuff marker, and its LO is generally in the middle part of the upper Paleocene (Gradstein and Kaminski, unpublished data).

3. Hormosina ovulum ovulum-In the Carpathian region the LO of this species is generally understood to occur at the top of the Paleocene (Geroch and Nowak, 1984), but in the Skole basin Morgiel and Szymakowska (1978) have reported it to occur in the lowermost Eocene. We have observed its LO in the abyssal North Atlantic within an undated interval between nannofossil Zones NP13 and NP15 in ODP Hole 647 and in an interval of roughly equivalent age in Hole 643A. 
Table 2. Benthic foraminifer abundance data from ODP Hole 767C. $R=$ rare, $1-3$ specimens; $F=$ frequent, $4-9$ specimens; $C=$ common, $10-20$ specimens; $\mathrm{A}=$ abundant, 30 or more specimens.

\begin{tabular}{|c|c|c|c|c|c|c|c|c|c|c|c|c|c|}
\hline $\begin{array}{rr} & \begin{array}{r}\text { Core-Section: } \\
\text { Interval in cm: } \\
\text { AGE: } \\
\\
\text { No. of species: }\end{array} \\
\end{array}$ & $\begin{array}{l}6 R-1 \\
22-25 \\
\text { Olig } \\
8\end{array}$ & $\begin{array}{c}6 \mathrm{R}-2 \\
34-37 \\
\text { Olig } \\
5\end{array}$ & $\begin{array}{c}6 \mathrm{R}-5 \\
13-17 \\
\text { Olig } \\
20\end{array}$ & $\begin{array}{c}7 R-2 \\
40-45 \\
\text { Olig } \\
4\end{array}$ & $\begin{array}{l}8 \mathrm{R}-1 \\
61-65 \\
\text { Olig } \\
6\end{array}$ & $\begin{array}{c}8 \mathrm{R}-2 \\
30-34 \\
\text { Olig } \\
8\end{array}$ & $\begin{array}{c}8 \mathrm{R}-3 \\
15-18 \\
\text { Olig } \\
6\end{array}$ & $\begin{array}{c}\text { 9R-1 } \\
72-77 \\
\text { E. Eoc. } \\
21\end{array}$ & $\begin{array}{l}\text { 9R-3 } \\
69-74 \\
\text { E. Eoc. } \\
19\end{array}$ & $\begin{array}{l}11 R-1 \\
54-57 \\
\text { E. Eoc. } \\
15\end{array}$ & $\begin{array}{l}11 R-2 \\
57-60 \\
\text { E. Eoc. } \\
14\end{array}$ & $\begin{array}{l}12 \mathrm{R}-1 \\
59-63 \\
\text { E. Eoc. } \\
\quad 2\end{array}$ & $\begin{array}{c}12 R-2 \\
110-114 \\
\text { E. Eoc. } \\
1\end{array}$ \\
\hline Rhizammina indivisa & C & C & C & $\bar{F}$ & $\mathrm{~F}$ & $\mathrm{~F}$ & $\bar{F}$ & $\mathrm{C}$ & $\mathrm{C}$ & C & C & $F$ & $\mathrm{~F}$ \\
\hline Ammosphaeroidina pseudopauciloculata & & & & & R & & & R & $\mathrm{R}$ & & & & \\
\hline Hyperammina spp. & $\mathrm{R}$ & & & & & & & & $\mathrm{F}$ & R & R & & \\
\hline Lituotuba lituiformis & & & & & & & & R & & & R & & \\
\hline $\begin{array}{l}\text { Reophax nodulosus } \\
\text { Hormosinella sp. }\end{array}$ & & & & & & R & & R & & $\mathrm{R}$ & $\mathrm{R}$ & & \\
\hline Glomospira charoides & & & R & $\mathbf{R}$ & & R & & $\mathrm{F}$ & R & $\mathbf{R}$ & R & & \\
\hline Glomospira gordialis & & R & R & & & & & & & & & & \\
\hline Glomospira glomerata & & & R & & & & & $\mathrm{R}$ & & & & & \\
\hline Ammodiscus tenuissimus & & & & & & & & R & R & & & & \\
\hline Rhabdammina spp. & & & c & R & c & R & & & $\mathrm{F}$ & C & c & & \\
\hline Ammodiscus latus & R & R & $\mathbf{R}$ & & $\mathrm{F}$ & $\mathrm{R}$ & & $\mathrm{R}$ & R & R & & & \\
\hline Reophax elongatus & $\mathrm{F}$ & & $\mathrm{F}$ & & & R & $\mathbf{R}$ & & & & & & \\
\hline Bathysiphon spp. & $\mathrm{F}$ & $\mathrm{F}$ & c & & $\mathrm{F}$ & & $\mathbf{R}$ & c & C & $\mathrm{F}$ & $\mathrm{F}$ & & \\
\hline Haplophragmoides walteri walteri & $\mathbf{R}$ & & R & & & & & $\mathrm{F}$ & $\mathrm{F}$ & $\mathrm{R}$ & R & & \\
\hline $\begin{array}{l}\text { Glomospira irregularis } \\
\text { Ammodiscus peruvianus }\end{array}$ & & & R & & R & & & $\mathrm{F}$ & $\mathrm{F}$ & R & R & & \\
\hline Hormosina velascoensis & & & & & & & R & & R & & & & \\
\hline Trochamminoides variolarius & & & & & & & & & & & & & \\
\hline Saccammina grzybowskii & & & R & & & & & $\mathrm{F}$ & & & & & \\
\hline Haplophragmoides walteri excavatus & & & $\mathrm{R}$ & & & & & & & & $\mathrm{R}$ & & \\
\hline Psammosphaera sp. & & & & & & & & & & R & R & & \\
\hline Cyclammina placenta & & & & & & & & R & $\mathrm{R}$ & & & & \\
\hline Reticulophragmium amplectens & $\mathrm{F}$ & & $\mathrm{F}$ & $\mathrm{R}$ & & R & & & & & & & \\
\hline Hormosinella distans & $\mathrm{F}$ & & $\mathrm{F}$ & & & & & & & $\mathrm{R}$ & & & \\
\hline Dendrophrya robusta & & $\mathrm{F}$ & $\mathrm{F}$ & & & R & & R & $\mathrm{F}$ & $\mathrm{F}$ & R & & \\
\hline Reophax pilulifer & & & R & & & & & R & & & & & \\
\hline Haplophragmoides horridus & & & R & & & & & & & R & & & \\
\hline Bathysiphon microrhaphidus & & & $\mathrm{F}$ & & & & & & & R & & & \\
\hline Recurvoides walteri & & & $\mathrm{F}$ & & & & & & & & & & \\
\hline Karrerulina conversa & & & R & & & & & & & & & & \\
\hline Tolypammina sp. & & & & & & & R & & & & & & \\
\hline Dendrophrya latissima & & & & & & & $\mathrm{R}$ & & & & & & \\
\hline Kalamopsis grzybowskii & & & & & & & & $\mathrm{R}$ & & & & & \\
\hline Trochamminoides subcoronatus & & & & & & & & R & & & & & \\
\hline Hormosina ovulum ovulum & & & & & & & & R & & & & & \\
\hline Karrerulina horrida & & & & & & & & $\mathrm{R}$ & & & & & \\
\hline Spiroplectammina spectabilis & & & & & & & & R & & & & & \\
\hline Hormosina ovuloides & & & & & & & & R & & & R & & \\
\hline Glomospira sp. & & & & & & & & & R & & & & \\
\hline Subreophax scalaris & & & & & & & & & $\mathrm{F}$ & & & & \\
\hline Hyperammina rugosa & & & & & & & & & $\mathrm{R}$ & & & & \\
\hline Rzehakina epigona minima & & & & & & & & & R & & & & \\
\hline Praecystammina sp. & & & & & & & & & $\mathrm{R}$ & & & & \\
\hline Psammosphaera fusca & & & & & & & & & $\mathrm{R}$ & & & & \\
\hline Paratrochamminoides spp. & & & & & & & & & & A & $\mathrm{R}$ & R & \\
\hline
\end{tabular}

4. Praecystammina sp.-This is a distinctive form first described by Krasheninnikov (1973) from the Upper Cretaceous of the western Pacific. In the abyssal red clays of the North Atlantic region, the LO of this genus is generally within the Upper Cretaceous, but it persists into the Paleocene in bathyal areas (Kuhnt and Kaminski, 1989). It has a consistent LO within the lowermost Eocene tuff sequence in the central North Sea (Gradstein and Kaminski, unpublished data), and near the lower/middle Eocene boundary in the Norwegian Sea (Kaminski et al., 1990).

5. Cyclammina placenta-This species is the immediate ancestor of the Holocene species Cyclammina cancellata Brady, and first evolved during the early Eocene. This species evolved from a Haplophragmoides ancestor and displays an evolutionary trend toward larger size and a more complex aperture (Berggren and Kaminski, 1990). The ancestral populations of $C$. placenta from the lower Eocene in the North
Atlantic are small, display no visible holes in the apertural face, and have only a single, interiomarginal aperture. Specimens from Hole $767 \mathrm{C}$ (Pl. 3, Fig. 6) are primitive morphotypes, similar to the ancestral populations from the North Atlantic. The specimens from Core 124-767C-9R are even smaller than lower Eocene specimens from the sediments directly overlying basement at Site 643 in the Norwegian Sea, which was drilled on marine magnetic Anomaly 23 (and correlates with the middle part of the early Eocene).

6. Paratrocham 2 minoides spp.-Throughout the flysch basins of the Polish Carpathians, a distinct horizon of reddish sediments contains common to abundant specimens of Trochamminoides and Paratrochamminoides. Jurkiewicz (1967) regarded this assemblage to be lower Eocene. In their detailed study of the Skole Basin of the Carpathians, Morgiel and Szymakowska (1978) subdivided the lower Eocene into three characteristic assemblages, the lowermost of which they 
termed the "Recurvoides-Trochamminoides" assemblage. In the central North Sea, the LO of Trochamminoides is observed in the lowermost Eocene Coscinodiscus Zone of Gradstein et al. (1988), and this also is usually an interval of reddish sediments. Although the occurrence of Trochamminoides and Paratrochamminoides in Hole $767 \mathrm{C}$ is not abundant, these forms are not found above Core 124-767C-9R.

7. Reticulophragmium amplectens-The FO of this species was observed in Sample 124-767C-8R-2, 30-34 cm, and its occurrence characterizes the overlying assemblage. The common occurrence of species is regarded as a good indicator of middle Eocene in the Carpathian flysch basins, although it occurs sporadically in older strata. Its oldest well-calibrated occurrence in the Carpathians is within nannofossil Zone NP12 (Olszewska and Smagowicz, 1977). We have documented its FO in the southern Labrador Sea in the upper portion of Zone NP11 (Kaminski et al., 1989).

In summary, using the benthic foraminifer data in isolation yields an early Eocene age for the base of the sediment section for the interval of Cores $124-767 \mathrm{C}-9 \mathrm{R}$ to $124-767 \mathrm{C}-11 \mathrm{R}$. If anything, the section correlates with the earliest Eocene (older than Zone NP12) DWAF assemblages in the Carpathians and North Atlantic. Our early Eocene age assignment (approx. $55 \mathrm{Ma}$ ) is in general agreement with the age of 50-55 Ma that Weissel (1980) estimated using the empirical age-depth curve, but remains in conflict with the interpreted magnetic anomalies in the basin (Weissel, 1980) and the middle Eocene age determined by shipboard analysis of radiolarians (Leg 124 Shipboard Scientific Party, 1989a, 1989 b). The benthic foraminifer assemblages at Site 767 consist of cosmopolitan deep-water forms. Because the sequence of benthic foraminifer FO's and LO's at Site 767 is so similar to the Atlantic-Mediterranean record, we have no reason to assume that the Celebes Sea contained a relict or peripherally isolated fauna that may have contained species that survived extinction in the main population. We urge reassessment of the available geophysical and micropaleontologic data to resolve this apparent conflict.

\section{The Eocene-Oligocene Hiatus}

In localities where special studies of Eocene to Oligocene DWAF have been carried out, the Eocene/Oligocene boundary is usually represented by an abrupt taxonomic turnover and a reduction in abundance and diversity. For example, at ODP Site 647, where the Eocene/Oligocene boundary was continuous, the LO's of 12 species were observed within $3 \mathrm{~m}$ of the boundary, and the lowermost Oligocene assemblages consisted mainly of Ammodiscus and Glomospira (Kaminski et al., 1989). In the marginal basins of the North Atlantic, as well as at Site 647, an important indicator species is Spiroplectammina spectabilis (Grzybowski). This species has never been observed above the Eocene/Oligocene boundary. At Site 767 , a similar change is observed between benthic foraminifer assemblages 1 and 2, between Cores 124-767C-9R and 124-767C-8R. Spiroplectammina spectabilis was not observed above Core 124-767C-9R, and all the remaining species comprising Assemblage 2 are known to range from the Eocene to the lower Oligocene in the Atlantic region. This corroborates the age assignment of early Oligocene for Core 124$767 \mathrm{C}-8 \mathrm{R}$ based on radiolarians (Fig. 2). However, because we interpret the benthic foraminifer assemblages from Core 124$767 \mathrm{C}-9 \mathrm{R}$ as earliest Eocene, a significant hiatus or extremely condensed interval must exist between Sample 124-767C9R-1, 72-77 cm, and Sample 124-767C-8R, CC, which contains lower Oligocene radiolarians.

\section{CONCLUSIONS}

1. Eocene to Oligocene deep-water agglutinated assemblages in lithologic Unit 4 of Holes 767B and 767C consist of cosmopolitan species that display strong affinities to coeval assemblages described from the North Atlantic and western Tethys. The biostratigraphic record at Site 767 appears to reflect global, rather than local events. This observation supports the idea that the Celebes Sea is a trapped fragment of ocean crust that originated in an open ocean setting (e.g., Leg 124 Shipboard Scientific Party, 1989a).

2. The early Eocene age for the base of the sediment section determined in this study is derived from several lines of faunal evidence and is in apparent conflict with the middle Eocene age determined by marine magnetic anomaly survey and shipboard biostratigraphic analyses.

3. A comparison between radiolarian and benthic foraminifer biostratigraphy indicates that a significant hiatus or extremely condensed interval exists between 753.0 and 753.7 mbsf.

\section{ACKNOWLEDGMENTS}

We gratefully acknowledge the Ocean Drilling Program for providing samples. Travel support for Z. H. to participate on Leg 124 was provided by an NSERC Strategic Grant to Ron Boyd (Dalhousie University). We thank Herb McDaniel and Danuta Kaminski for help with sample preparation. We are grateful to W. A. Berggren and R. W. Jones for reviewing the manuscript. This is contribution No. 28 of the Deep-Water Agglutinated Foraminifera Project, supported by a consortium of oil companies (BP, Chevron, Marathon, Texaco, UNOCAL) under a grant to W. A. Berggren (Woods Hole Oceanographic Institution).

\section{REFERENCES}

Berggren, W. A., and Kaminski, M. A., 1990. Abyssal agglutinates: back to basics. In Hemleben, C., Kaminski, M. A., Kuhnt, W., and Scott, D. B. (Eds.), Paleoecology, Biostratigraphy, Paleoceanography and Taxonomy of Agglutinated Foraminifera. NATO ASI Series C, Dordrecht (Kluwer Acad. Publ.), 327:53-75.

Charnock, M. A., and Jones, R. W., 1990. Agglutinated foraminifera from the Palaeogene of the North Sea. In Hemleben, C., Kaminski, M. A., Kuhnt, W., and Scott, D. B. (Eds.), Paleoecology, Biostratigraphy, Paleoceanography and Taxonomy of Agglutinated Foraminifera. NATO ASI Series C, Dordrecht (Kluwer Acad. Publ.), 327:139-244.

Cushman, J. A., and Renz, H. H., 1946. The foraminiferal fauna of the Lizard Springs Formation of Trinidad, British West Indies. Cushman Lab. for Foraminiferal Res., Spec. Publ. 18:1-48.

Geroch, S. and Koszarski, L., 1988. Agglutinated foraminiferal stratigraphy of the Silesian Flysch Trough. In Gradstein, F. M., and Rögl, F. (Eds.), Second International Workshop on Agglutinated Foraminifera (Vienna 1986), Proceedings. Abh. Geol. Bundesanst (Wien), 41:73-80.

Geroch, S., and Nowak, W., 1984. Proposal of zonation for the late Tithonian-late Eocene, based upon arenaceous foraminifera from the outer Carpathians, Poland. In Oertli, H. J. (Ed.), Benthos '83, 2nd Int. Symp. Benthic Foraminifera (Pau, April 1983), 225-239.

Gradstein, F. M., Kristiansen, I. L., Lomo, L., and Kaminski, M. A., in press. Cenozoic foraminiferal and dinoflagellate biostratigraphy of the central North Sea. Rev. Paleobot., Palynol.

Gradstein, F. M., Kaminski, M. A., and Berggren, W. A., 1988. Cenozoic foraminiferal biostratigraphy, central North Sea. In Rögl, F., and Gradstein, F. M. (Eds.), Second Workshop on Agglutinated Foraminifera (Vienna 1986), Proceedings. Abh. Geol. Bundesanstalt (Wien), 41:97-108.

Haig, D. W., 1982. Deep-sea foraminiferids from Paleocene sediments, Port Moresby, Papua New Guinea. J. Foramiferal Res., $12: 287-297$. 
Jurkiewicz, H., 1967. Foraminifers in the Sub-Menilitic Paleogene of the Polish Middle Carpathians. Inst. Geol. Biul., 210:5-102.

Kaminski, M. A., Gradstein, F. M., and Berggren, W. A., 1989. Paleogene benthic foraminifer biostratigraphy and paleoecology at Site 647, southern Labrador Sea. In Srivastava, S. P., Arthur, M. A., and Clement, B., et al., Proc. ODP, Sci. Results, 105: College Station, TX (Ocean Drilling Program), 705-730.

Kaminski, M. A., Gradstein, F. M., Berggren, W. A., Geroch, S. and Beckmann, J.-P., 1988. Flysch-type agglutinated foraminiferal assemblages from Trinidad: taxonomy, stratigraphy and paleobathymetry.In Rögl, F., and Gradstein, F. M., (Eds.), Second Workshop on Agglutinated Foraminifera (Vienna 1986), Proceedings. Abh. Geol. Bundesanstalt (Wien), 41:155-227.

Kaminski, M. A., Gradstein, F. M., Goll, R. M., and Grieg, D., 1990. Biostratigraphy and paleoecology of deep-water agglutinated foraminifera at ODP Ste 643, Norwegian-Greenland Sea. In Hemleben, C., Kaminski, M. A., Kuhnt, W., and Scott, D. B. (Eds.), Paleoecology, Biostratigraphy, Paleoceanography and Taxonomy of Agglutinated Foraminifera. NATO ASI Series C, Dordrecht (Kluwer Acad. Publ.), 327:345-386.

Krasheninnikov, V. A., 1973. Cretaceous benthonic foraminifera, Leg 20, Deep Sea Drilling Project. In7 Heezen, B. C., MacGregor, I. D., et al., Init. Repts. DSDP, 20: Washington (U.S. Government Printing Office), 205-221.

Kuhnt, W., and Kaminski, M. A., 1989. Upper Cretaceous deepwater agglutinated benthic foraminiferal assemblages from the western Mediterranean and adjacent areas. In Wiedmann, J. (Ed.), Cretaceous of the Western Tethys. Proc. 3rd Int. Cretaceous Symposium, Tübingen., 1121-1140.

Leg 124 Shipboard Scientific Party, 1989a. Origins of Marginal Basins. Nature, 338:380-381.
Leg 124 Shipboard Scientific Party, 1989b. Leg 124 researchers drill marginal basins. Geotimes, 34:15-17.

Morgiel, J., and Szymakowska, F., 1978. Stratigrafia Paleocenu i Eocenu Jednostki Skolskiej. Inst. Geol. Biul., 310:39-71.

Olszewska, B., and Smagowicz, M., 1977. Porównanie podzialow biostratigraficznych górnej kredy i paleogenu Jednostki Dukielskiej na podstawie otwornic planktonicznych i nannoplanktonu wapiennego. Przeglad Geol., 271:359-363.

Parsons, B., and Sclater, J. G., 1977. An analysis of the variation of ocean floor bathymetry and heat flow with age. J. Geophys. Res., 82:803-827.

Sclater, J. G., Anderson, R. N., and Bell, M. L., 1971. Elevation of ridges and evolution of the central eastern Pacific. J. Geophys. Res., 76:7888-7915.

Shipboard Scientific Party, 1990. Site 767. In Rangin, C., Silver, E. A., von Breymann, M., et al., Proc. ODP, Init. Repts., 124: College Station, TX (Ocean Drilling Program), 121-193.

Webb, P. N. 1975. Paleocene foraminifera from DSDP Site 283, South Tasman Basin. In Kennett, J. P., Houtz, R. E., et al., Init. Repts. DSDP, 29: Washington (U.S. Government Printing Office), 833 843.

Weissel, J. K., 1980. Evidence for Eocene oceanic crust in the Celebes Basin. Geophys. Monogr., 23:37-47.

Date of initial receipt: 17 July 1990

Date of acceptance: 10 December 1990

Ms 124B-131 


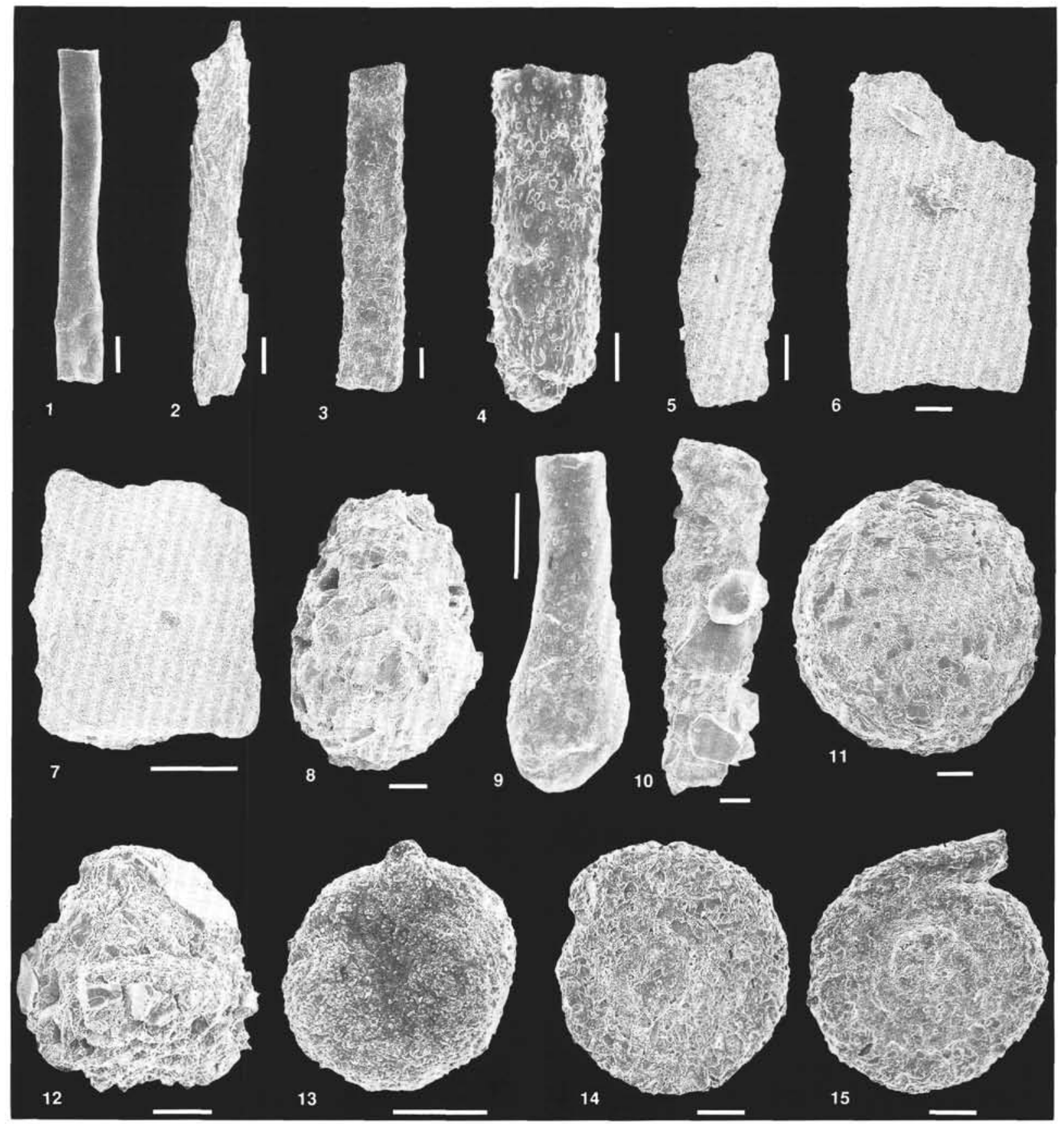

Plate 1. All scale bars are $100 \mu \mathrm{m}$, except Figure 7, which is $300 \mu \mathrm{m}$. 1. Bathysiphon sp., Sample 124-767C-9R-3, 69-74 cm. 2. Bathysiphon microrhaphidus Samuel, Sample 124-767C-6R-5, 13-17 cm. 3. Rhizammina indivisa Brady, Sample 124-767C-9R-3, 69-74 cm. 4. Rhabdammina cylindrica Glaessner, Sample 124-767B-75X-4, 45-48 cm. 5. Rhabdammina sp. Sample 124-767C-11R-1, 54-57 cm. 6. Dendrophrya latissima Grzybowski, Sample 124-767C-8R-3, 15-18 cm. 7. Dendrophrya robusta Grzybowski, Sample 124-767C-8R-2, 30-34 cm; scale bar $=300 \mu \mathrm{m}$. 8. Hyperammina sp. Sample 124-767B-77X-2, 30-34 cm. 9. Hyperammina elongata Brady, Sample 124-767C-11R-1, 54-57 cm. 10. Hyperammina rugosa Verdenius and Van Hinte, Sample 124-767C-9R-3, 69-74 cm. 11. Psammosphaera sp., Sample 124-767C-11R-2, 57-60 cm. 12. Psammosphaera fusca Schultze, Sample 124-767C-9R-3, 69-74 cm. 13. Saccammina grzybowskii (Schubert), Sample 124-767C-9R-1, 72-77 cm. 14. Ammodiscus latus Grzybowski, megalosphaeric form, Sample 124-767C-8R-2, 30-34 cm. 15. Ammodiscus latus Grzybowski, microsphaeric form, Sample 124-767B-75X-4, 45-48 cm. 


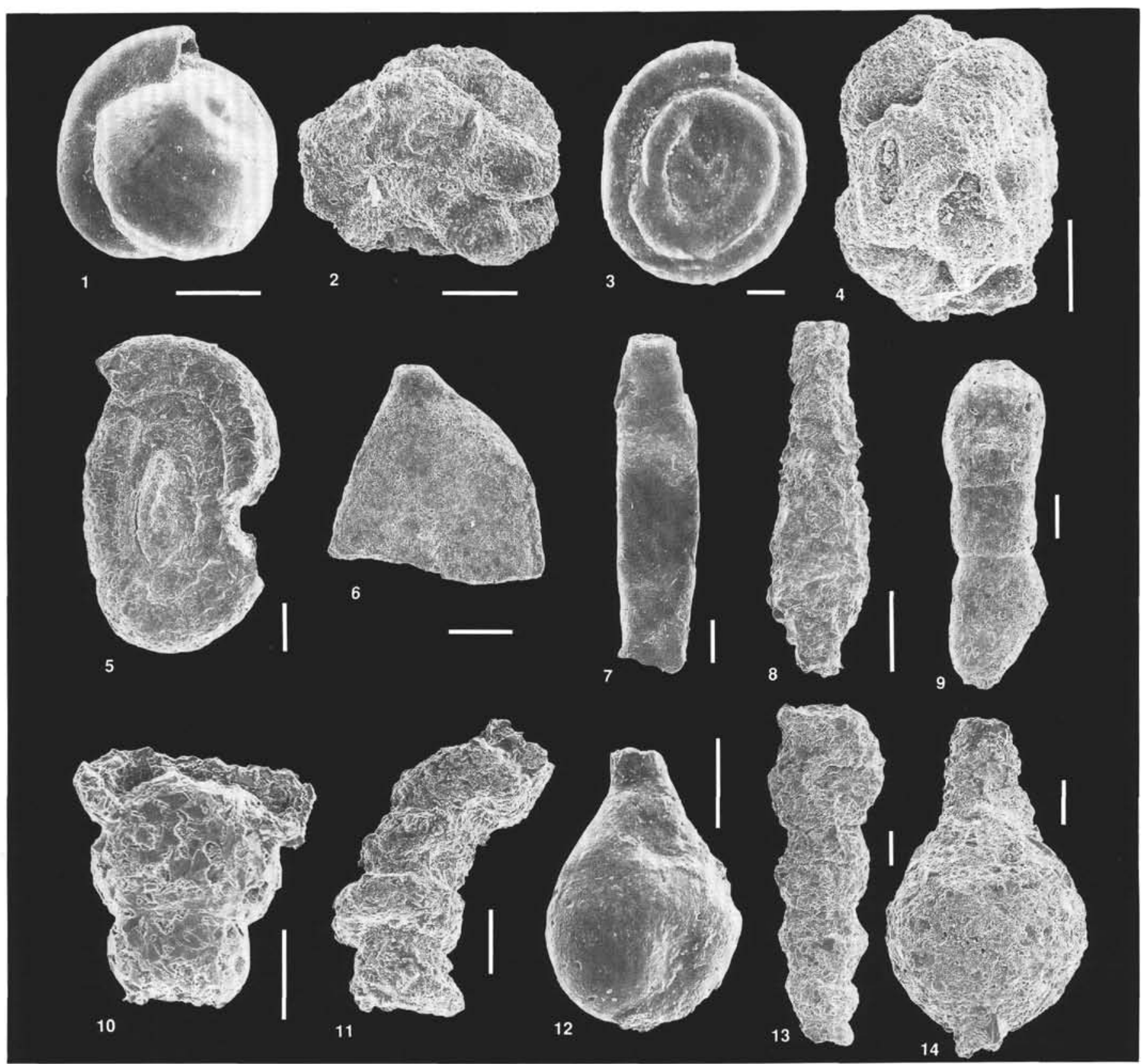

Plate 2. Scale bar in Figure 8 is $300 \mu \mathrm{m}$ and in Figure 3 is $30 \mu \mathrm{m}$; all others are $100 \mu \mathrm{m}$. 1. Glomospira charoides (Jones and Parker), Sample 124-767C-8R-2, 30-34 cm. 2. Glomospira glomerata (Grzybowski), Sample 124-767C-6R-5, 13-17 cm. 3. Glomospira gordialis (Jones and Parker), Sample 124-767B-76X-2, 111-113 cm; scale $=30 \mu \mathrm{m} .4$. Glomospira irregularis (Grzybowski), Sample 124-767C-8R-1, 61-65 cm. 5. Glomospirella sp., Sample 124-767C-6R-1, 22-25 cm. 6. Rzehakina epigona minima Cushman and Renz, Sample 124-767C-9R-3, 69-74 cm. 7. Kalamopsis grzybowskii (Dylazanka), Sample 124-767C-9R-1, 72-77 cm. 8. Reophax elongatus Grzybowski, Sample 124-767C-8R-2, 30-34 cm; scale $=300 \mu \mathrm{m}$. 9. Reophax nodulosus Brady, Sample 124-767C-11R-1, 54-57 cm. 10. Reophax pilulifer Brady, Sample 124-767C-6R-5, 13-17 $\mathrm{cm}$. 11. Subreophax scalaris (Grzybowski), Sample 124-767C-9R-3, 69-74 cm. 12. Hormosina ovulum ovulum (Grzybowski), Sample 124-767C-9R-1, 72-77 cm. 13. Hormosina velascoensis (Cushman), Sample 124-767C-8R-3, 15-18 cm. 14. Hormosinella distans (Brady), Sample 124-767C-6R-5, 13-17 cm. 


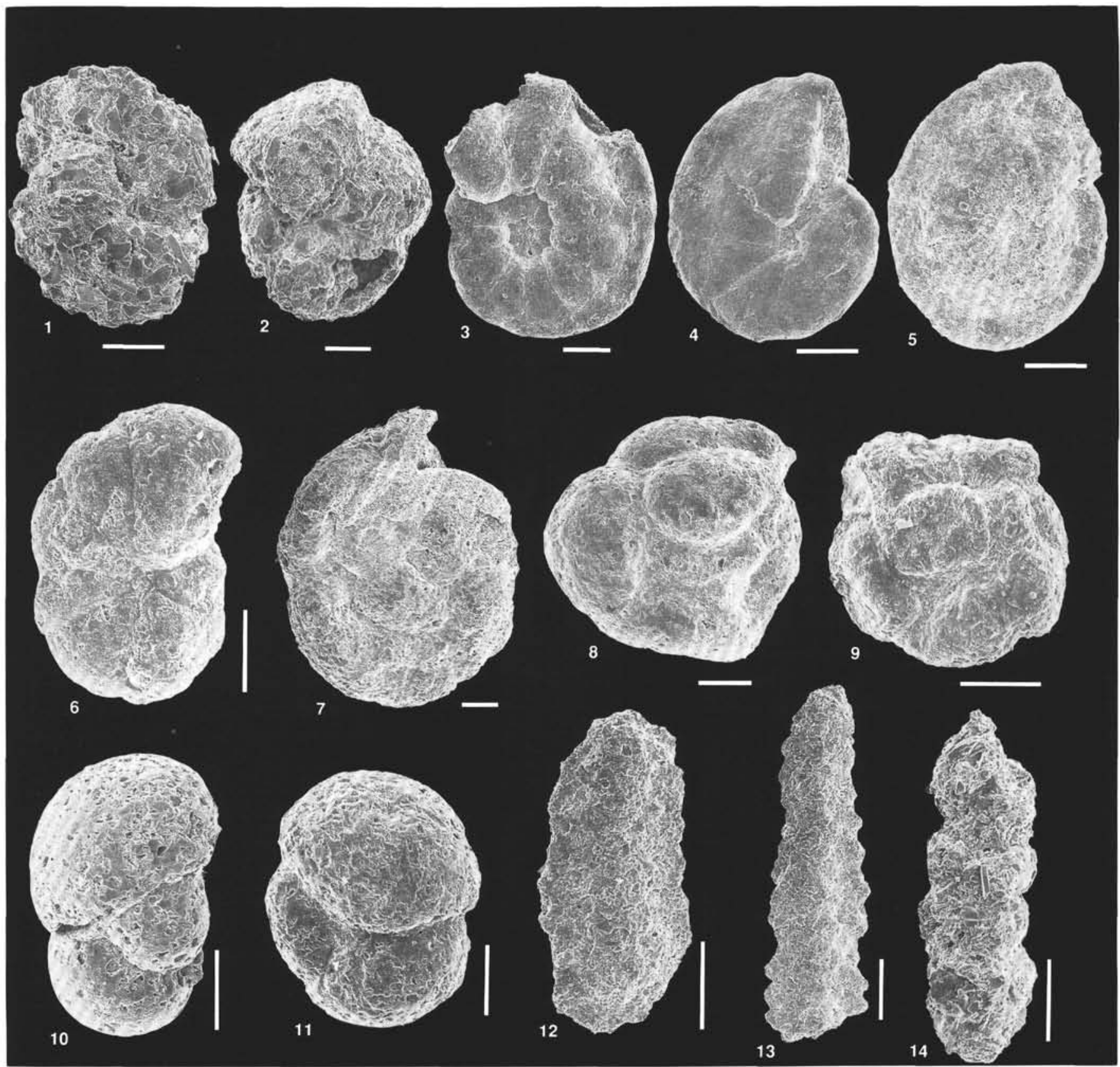

Plate 3. All scale bars $=100 \mu \mathrm{m}$. 1. Cribrostomoides sp., Sample 124-767B-77X-2, 30-34 cm. 2. Haplophragmoides horridus (Grzybowski), Sample 124-767C-6R-5, 13-17 cm. 3. Haplophragmoides walteri excavatus Cushman and Waters, Sample 124-767C$11 \mathrm{R}-2,57-60 \mathrm{~cm}$. 4. Haplophragmoides walteri walteri (Grzybowski), Sample 124-767C-6R-1, 22-25 cm. 5. Reticulophragmium amplectens (Grzybowski), Sample 124-767B-75X-1, 45-48 cm. 6. Cyclammina placenta (Reuss), Sample 124-767C-9R-1, 72-77 cm. 7. Paratrochamminoides sp., Sample 124-767C-11R-1, 54-57 cm. 8. Paratrochamminoides sp., Sample 124-767C-11R-1, 54-57 cm. 9. Trochamminoides variolarius (Grzybowski), Sample 124-767B-76X-6, 6-9 cm. 10. Praecystammina sp., Sample 124-767C-9R-3, 69-74 $\mathrm{cm}$. 11. Ammosphaeroidina pseudopauciloculata (Mjatliuk), Sample 124-767C-9R-3, 69-74 cm. 12. Spiroplectammina spectabilis (Grzybowski), megalosphaeric form, Sample 124-767C-9R-1, 72-77 cm. 13. Spiroplectammina spectabilis (Grzybowski), microsphaeric form, Sample 124-767C-9R-1, 72-77 cm. 14. Karrerulina conversa (Grzybowski), Sample 124-767C-6R-5, $13-17 \mathrm{~cm}$. 